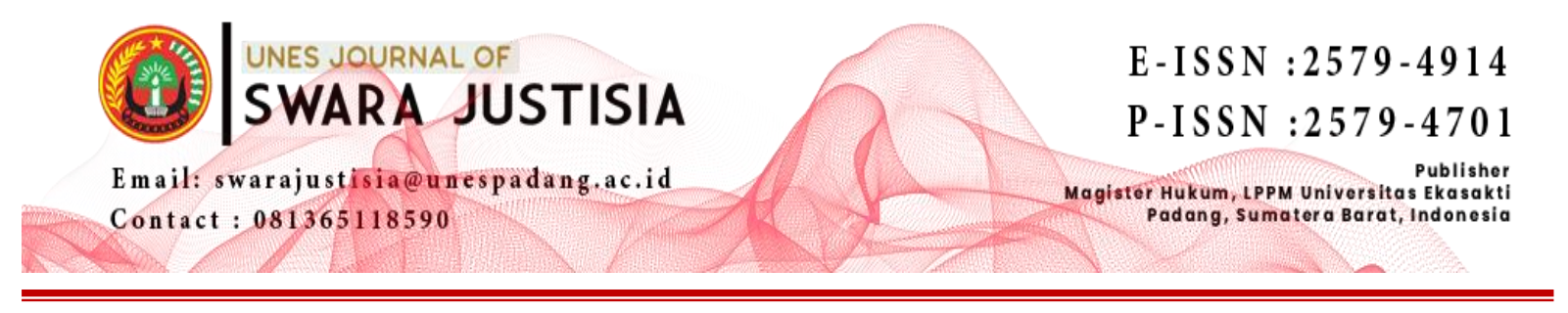

\title{
PENGARUH PENERAPAN SANKSI BAGI SISWA PENDIDIKAN BINTARA POLRI YANG MELAKUKAN TINDAK PIDANA TERHADAP KINERJA BINTARA REMAJA DI POLDA SUMBAR
}

\author{
${ }^{1}$ Hanif Kurniawan, ${ }^{2}$ Fitriati, ${ }^{3}$ Iyah Faniyah \\ ${ }^{1}$ Program Magister Ilmu Hukum, Universitas Ekasakti, Padang, Indonesia \\ Email: hankuga@gmail.com \\ ${ }^{2}$ Program Magister Ilmu Hukum, Universitas Ekasakti, Padang, Indonesia \\ Email: fitriati@gmail.com \\ ${ }^{3}$ Program Magister Ilmu Hukum, Universitas Ekasakti, Padang, Indonesia \\ Email: iyahfaniyah01@gmail.com
}

\begin{abstract}
In Article 15 Paragraph (5) letter c of the Chief of Police Regulation Number 11 of 2009 concerning the Principles of the implementation of education and training in state police schools, which stipulates that a non-commissioned officer who is still studying at the State Police School may not commit a crime and/or violation of the Police code of ethics, disobeying and respecting the norms of decency, religious norms, local wisdom values, and legal norms. Forms of criminal acts committed by a student of Diktukba Polri SPN Padang Besi Polda West Sumatra, including fighting, stealing, immoral acts and falsifying identity. The implementation of sanctions for students of the National Police's Diktukba who commit criminal acts are punished in the form of giving a red helmet, reducing the mental value of personality, forming mental and character and being expelled from education. The authority to give punishment lies with the Head of the Educational Institution. The effect of sanctions for students of the National Police's Diktukba who commit criminal acts on performance when being non-commissioned officers is that there is no effect of sanctions for students of the National Police dictatorship who commit criminal acts on performance when noncommissioned officers are adolescents, seen in attitudes and behavior when carrying out tasks, this is indicated by the sanctions given and the award received when being noncommissioned officer for youth from the data of 408 people, the number of students in the 2017 and 2018 class was sanctioned by 127 people and who received a reward of 18 people, while based on the questionnaire given to respondents, it was stated that there was an important influence on the sanctions given to Diktukba Polri students who committing a criminal act, which has a deterrent effect, shaping the mental personality, psychology and character of the student who committed the crime and also other fellow students so that when they become non-commissioned youth they do not violate the police code of ethics.
\end{abstract}

Keywords: Students of Bintara Polri, Punishment, Criminal Actions, Youth Bintara

\begin{abstract}
ABSTRAK
Dalam Pasal 15 Ayat (5) huruf c Peraturan Kapolri Nomor 11 Tahun 2009 tentang Pokokpokok Penyelenggaraan Diklat Polri, yang mengatur bahwa seorang bintara yang masih menempuh pendidikan di Kepolisian Negara Sekolah tidak boleh melakukan tindak pidana
\end{abstract}


dan/atau pelanggaran kode etik Polri, tidak menaati dan menghormati norma kesusilaan, norma agama, nilai kearifan lokal, dan norma hukum. Bentuk-bentuk tindak pidana yang dilakukan oleh mahasiswa Diktukba Polri SPN Padang Besi Polda Sumatera Barat antara lain berkelahi, mencuri, melakukan perbuatan asusila dan memalsukan identitas. Pelaksanaan sanksi bagi mahasiswa Diktukba Polri yang melakukan tindak pidana berupa pemberian helm merah, pengurangan nilai mental kepribadian, pembentukan mental dan budi pekerti serta dikeluarkan dari pendidikan. Kewenangan untuk memberikan hukuman berada pada Kepala Lembaga Pendidikan. Pengaruh sanksi bagi mahasiswa Diktukba Polri yang melakukan tindak pidana terhadap kinerja saat menjadi bintara adalah tidak ada pengaruh sanksi bagi mahasiswa diktator Polri yang melakukan tindak pidana terhadap kinerja apabila bintara tersebut remaja dilihat dari sikap dan perilaku saat melaksanakan tugas, hal ini ditunjukkan dengan sanksi yang diberikan dan penghargaan yang diterima saat menjadi bintara kepemudaan dari data 408 orang, jumlah siswa angkatan 2017 dan 2018 terkena sanksi sebanyak 127 orang dan yang mendapatkan reward sebanyak 18 orang, sedangkan berdasarkan kuesioner yang diberikan kepada responden disebutkan bahwa terdapat pengaruh penting sanksi yang diberikan kepada mahasiswa Diktukba Polri yang melakukan tindak pidana yaitu memberikan efek jera, membentuk mental kepribadian, psikologi dan watak mahasiswa yang melakukan tindak pidana dan juga sesama mahasiswa lainnya sehingga pada saat; y menjadi pemuda binaan mereka tidak melanggar kode etik kepolisian.

Kata Kunci: Penerapan Sanksi, Pendidikan Bintara Polri, Tindak Pidana, Kinerja Bintara

\section{PENDAHULUAN}

Dalam Pasal 15 Ayat (5) huruf c Peraturan Kapolri Nomor 11 Tahun 2009 tentang pokok-pokok penyelenggaraan pendidikan dan pelatihan di sekolah polisi negara mengatur bahwa seorang Siswa Bintara yang masih berstatus melakukan pendidikan di Sekolah Polisi Negara tidak boleh melakukan tindak pidana dan/atau pelanggaran kode etik Kepolisian, tidak mentaati dan menghormati norma kesusilaan, norma agama, nilai-nilai kerarifan lokal, dan norma hukum. Bentuk tindak pidana yang dilakukan seorang siswa diktukba polri SPN Padang Besi Polda Sumatera Barat antara lain berkelahi, mencuri, tindakan asusila dan memalsukan identitas.

Sikap perilaku dan disiplin anggota Polri dalam melaksanakan tugasnya sebagai pelindung, pengayom dan pelayan masyarakat serta sebagai aparat penegak hukum dan pemelihara Kamtibmas, harus dapat dijadikan tauladan oleh seluruh lapisan masyarakat yang dilayaninya. Hal itu akan sangat berpengaruh terhadap terciptanya citra Polri di mata masyarakat, demikian juga akan membentuk sikap simpatik dan mendorong masyarakat untuk ikut berpartisipasi serta membantu pelaksanaan tugas-tugas Kepolisian. ${ }^{1}$

Melayani dan melindungi merupakan tugas pokok Polri. Dalam memberikan pelayanan dan perlindungan kepada masyarakat, anggota Polri harus bersikap profesional. Profesionalisme anggota Polri dapat dilihat dari hasil kerja dan perilaku petugas tersebut dalam melayani masyarakat. Dalam setiap upaya untuk memperkokoh hubungan antar warga negara dan anggota polisi, etika pribadi dan sikap anggota polisi merupakan hal yang sangat penting. Setiap anggota Polri harus memahami bahwa dasar pelayanan polisi adalah semangat

1 Pudi Rahardi, Hukum Kepolisian, Profesionalisme dan Reformasi Polri, Laksbang Mediatama, Surabaya, 2007, hlm. 146. 
kemauan untuk melayani warga negara Indonesia guna mendapatkan rasa hormat dan kepercayaan dari masyarakat. $^{2}$

Berdasarkan Pasal 2 Undang-undang Nomor 2 Tahun 2002 tentang Kepolisian Negara Republik Indonesia, fungsi kepolisian adalah salah satu fungsi pemerintahan negara di bidang pemeliharaan keamanan dan ketertiban masyarakat, penegakan hukum, perlindungan, pengayoman dan pelayanan penegak hukum, polisi harus tunduk pada peraturan perundangundangan yang berlaku, salah satunya adalah peraturan mengatur tentang etika profesi yaitu Peraturan Kapolri Nomor 14 Tahun 2011 tentang Kode Etik Profesi Kepolisian.

Keberhasilan aplikasi etika kepolisian sebenarnya ditentukan oleh 3 (tiga) hal yaitu adanya pribadi yang teguh untuk berbuat etis, adanya pimpinan yang mengarahkan/ membimbing dan adanya masyarakat yang mendukung. Kelemahan pada ketiga unsur tersebut baik salah satu ataupun kesemuanya akan meniadakan perilaku etis polisi, yang hasilnya akan sangat destruktif/merusak. Dengan demikian pengembangan etika kepolisian dapat dilakukan apabila ketiga-tiganya dapat ditumbuhkan, dibangun dan dipupuk agar dapat subur dan berkembang dengan baik.

Dalam kode etik kepolisian, masyarakat. Dalam melaksanakan tugas dan fungsinya sebagai aparat salah satunya disebutkan bahwa setiap anggota Polri harus "menjauhkan diri dari perbuatan dan sikap tercela, serta mempelopori setiap tindakan mengatasi kesulitan masyarakat sekelilingnya". Disamping itu, setiap insan Polri juga diharapkan "mampu mengendalikan diri dari perbuatan-perbuatan penyalahgunaan wewenang".3

Pelanggaran kode etik Polri adalah setiap perbuatan yang dilakukan oleh anggota Polri yang bertentangan dengan kode etik profesi Polri. Ada beberapa faktor yang mempengaruhi terjadinya pelanggaran kode etik oleh anggota Polri, mulai dari turunnya integritas moral, hilangnya independensi, adanya tuntutan ekonomi, minimnya penghasilan, lemahnya pengawasan, sampai dengan ketidakpatuhan terhadap kode etik profesi hukum yang mengikatnya. ${ }^{4}$

Dalam hal terjadi pelanggaran kode etik maka telah ada prosedur tersendiri untuk penyelesaian pelanggaran kode di lingkungan Kepolisian Republik Indonesia. Termasuk dalam lingkungan pembentukan calon anggota Polri yaitu di Sekolah Polisi Negara. Sanksi kode etik ini juga terjadi kepada siswa Bintara Polri di Sekolah Polisi Negara Polda Sumatera Barat. Setidaknya ada 3 (tiga) kasus tindak pidana yang dilakukan oleh siswa Bintara Polri di Sekolah Polisi Negara Polda Sumatera Barat yaitu 2 kasus mencuri dan 1 kasus melakukan hubungan layaknya suami istri. Ketiga kasus tersebut merupakan pelanggaran tindak pidana yang dilakukan oleh siswa Bintara Polri Sekolah Polisi Negara Polda Sumatera Barat, sehingga diterapkan sanksi kode etik kepada para siswa tersebut.

Berdasarkan uraian di atas maka penulis tertarik untuk mengetahui dan menelitinya secara ilmiah dalam bentuk penelitian tesis dengan memilih judul: "Pengaruh Penerapan Sanksi Bagi Siswa Pendidikan Bintara Polri Yang Melakukan Tindak Pidana Terhadap Kinerja Bintara Remaja (Studi Di Polda Sumbar)".

\footnotetext{
${ }^{2}$ Kepolisian Republik Indonesia, Buku Panduan tentang Hak Asasi Manusia untuk Anggota Polri, PTIK, Jakarta, 2006, hlm. 27.

3 Dani Durahman, Penerapan Sanksi Terhadap Penyimpangan Penyidik Polri Dalam Menangani Perkara, Jurnal Ilmiah Universitas Batanghari Jambi Volume 16, Nomor 2 Tahun 2016, hlm. 47

${ }^{4}$ Dwi Haryadi, Kode Etik Profesi Hukum, UBPress, Malang, 2018, hlm. 12.
} 


\section{METODE PENELITIAN}

Penelitian ini merupakan penelitian deskriptif analitis yang menggambarkan tentang pengaruh sanksi bagi siswa Diktukba Polri yang melakukan tindak pidana terhadap kinerja saat menjadi bintara remaja di Polda Sumatera Barat.

Pendekatan yang digunakan dalam penelitian ini adalah pendekatan yuridis normatif dan pendekatan yuridis empiris. Yuridis normatif digunakan untuk mengetahui tentang aturan-aturan hukum yang berkenaan dengan pelaksanaan penerapan sanksi terhadap Siswa Bintara Polri yang melakukan pelanggaran kode etik di Sekolah Polisi Negara Polda Sumatera Barat. Sedangkan pendekatan yuridis empiris digunakan sebagai dukungan terhadap pendekatan yuridis normatif, yaitu untuk melihat pelaksanaan penerapan sanksi kode etik terhadap Siswa Bintara Bintara Polri yang melakukan tindak pidana di Sekolah Polisi Negara Polda Sumatera Barat.

Data yang digunakan dalam penelitian ada dua yaitu data primer dan data sekunder. Data primer diperoleh langsung dari sumbernya, baik melalui wawancara, dengan menggunakan instrument kuesioner terstruktur yang digunakan peneliti dalam wawancara dengan bintara remaja di Polda Sumatera Barat dengan total jumlah siswa sebanyak 408 orang dengan jumlah kuesioner sebanyak 80 sampel yang dipilih secara acak. Rentang pengisian kuesioner dari tanggal 15 Oktober 2020 sampai dengan 15 November 2020. Sedangkan data sekunder diperoleh dengan melakukan penelitian kepustakaan (library research) atau studi dokumen. Dengan mengadakan penelitian kepustakaan diperoleh data awal untuk digunakan dalam penelitian lapangan (field research).

\section{HASIL DAN PEMBAHASAN}

\section{A. Pelaksanaan Sanksi Bagi Siswa Diktukba Polri Yang Melakukan Tindak Pidana}

Berdasarkan data dari SPN Padang Besi pada tahun 2017 ada 220 orang siswa yang didik dan dilantik sebanyak 220 orang, tahun 2018 ada 188 orang siswa yang didik dan dilantik sebanyak 188 orang, tahun 2019 ada 257 orang siswa yang didik dan dilantik sebanyak 257 orang. Jumlah pelanggaran yang dilakukan siswa pada tahun 2017 sebanyak 136 kasus yang terdiri dari 115 pelanggaran ringan (tidak memberikan penghormatan 84 kasus dan tidak menjaga kebersihan dan kerapihan diri 52 kasus) atau $84,5 \%$ dari total seluruh jenis pelanggaran yang terjadi, 16 pelanggaran sedang (tidur saat mengikuti kegiatan 11 kasus dan terlambat mengikuti kegiatan 5 kasus) atau 11,7\% dari total seluruh jenis pelanggaran yang terjadi, 5 pelanggaran berat (berkelahi 3 kasus dan mencuri 2 kasus) atau 3,6 \%dari total seluruh jenis pelanggaran yang terjadi .

Pada tahun 2018 sebanyak 128 kasus yang terdiri dari 106 pelanggaran ringan (tidak memberikan penghormatan 75 kasus dan tidak menjaga kebersihan dan kerapihan diri 31 kasus) atau 82,8\% dari total seluruh jenis pelanggaran yang terjadi, 19 pelanggaran sedang (tidur saat mengikuti kegiatan 8 kasus dan terlambat mengikuti kegiatan 11 kasus) atau 14,8\% dari total seluruh jenis pelanggaran yang terjadi, 3 pelanggaran berat (berkelahi 1 kasus dan terlambat masuk kesatriaan dari IBL 2 kasus) atau 2,3\% dari total seluruh jenis pelanggaran yang terjadi. 


\section{B. Pengaruh Sanksi Bagi Siswa Diktukba Polri Yang Melakukan Tindak Pidana Terhadap Kinerja Saat Menjadi Bintara Remaja.}

Berdasarkan data dari Bidpropam Polda Sumbar bintara remaja yang terkena sanksi Tindakan Disiplin sebanyak 113 orang atau sebesar $27,7 \%$ dari jumlah total bintara remaja anggatan 2017-2018 dengan rincian 23 pelanggaran sikap tampang, 77 orang pelanggaran kelengkapan surat nyata diri dan 13 orang terlambat/tidak ikut apel. Sedangkan sebanyak 14 atau sebesar 3,4\% orang dari jumlah total bintara remaja anggatan 2017-2018 terkena sanksi hukuman disiplin yang disebabkan karena pelanggaran disiplin (memasuki tempat terlarang/tempat hiburan malam sebanyak 13 orang, merendahkan citra polri 1 orang. Data dari biro SDM Polda Sumbar bintara remaja yang mendapat penghargaan sebanyak 18 orang atau sebesar 4,4\% dari 408 orang total bintara remaja anggatan 2017-2018.

Berdasarkan kuesioner yang dibagikan secara acak kepada 80 bintara remaja dari total 408 orang bintara remaja angkatan 2017 dan 2018, dengan menggunakan google.docs, dengan alamat linknya: https://docs.google.com/forms/d/1T7 ITlrOzpy9araYybacfdhxIRkT1KWivN2x6rtRj-BU/edit dengan judul kuesioner "Pengaruh Sanksi Bagi Siswa Diktukba Polri Yang Melakukan Tindak Pidana Terhadap Kinerja Saat Menjadi Bintara Remaja" ada beberapa pertanyaan singkat yang diajukan oleh penulis, yaitu:

1) Nama dan Usia

2) Jenis Kelamin

3) Apakah anda pernah mendapatkan sanksi selama menjadi Siswa Diktukba Polri ?

4) Apakah anda mengetahui pelaksanaan Sanksi Bagi Siswa Diktukba Polri Yang Melakukan Tindak Pidana?

5) Bagaimana Pelaksanaan Sanksi Bagi Siswa Diktukba Polri Yang Melakukan Tindak Pidana menurut saudara?

6) Menurut anda apa pengaruh sanksi bagi siswa diktukba polri yang melakukan tindak pidana terhadap kinerja saat menjadi bintara remaja?

Pengsisian kuesioner ini dilakukan dari 15 September sampai dengan 15 November 2020. Berdasarkan pertanyaan no 1 "Nama dan Usia" jawaban dari responden berada pada rentang Usia dari Umur 19 Tahun sampai dengan Umur 23 tahun dengan rincian umur 19 tahun sebanyak 8 orang, umur 20 tahun sebanyak 16 orang, umur 21 tahun sebanyak 20 orang, umur 22 tahun sebanyak 23 orang, umur 23 tahun sebanyak 13 orang.

Berdasarkan pertanyaan no 2 "Jenis Kelamin" jawaban dari responden semua berjenis kelamin laki-laki. Berdasarkan pertanyaan no. 3 "Apakah anda pernah mendapatkan sanksi selama menjadi siswa Diktukba Polri" dari 80 responden, yang menjawab pernah sebanyak 21 responden (26,25\% dari total responden), dan yang menjawab tidak pernah 59 responden ( $73,75 \%$ dari total responden).

Berdasarkan pertanyaan no 6 "Menurut anda apa pengaruh sanksi bagi siswa diktukba polri yang melakukan tindak pidana terhadap kinerja saat menjadi bintara remaja ?" jawaban dari 80 responden sebanyak 46 orang (57,5\% dari total responden) menjawab sangat berpengaruh, untuk pembelajaran dan menimbulkan efek jera, 21 
responden $(26,25 \%$ dari total responden) menjawab sangat berpengaruh agar pada saat dinas tidak melakukan pelanggaran/tindak pidana, dan 13 responden (16,25\% dari total responden) menjawa Sangat berpengaruh untuk membentuk mental kepribadian, psikologi dan karakter.

Berdasarkan data dari SPN Padang Besi, bidpropam dan Biro SDM Polda Sumbar dapat dilihat pengaruh sanksi bagi siswa Diktukba Polri yang melakukan tindak pidana terhadap kinerja saat menjadi bintara remaja bisa disimpulkan bahwa tidak ada pengaruh dalam pelaksanaan sanksi bagi siswa Diktukba Polri yang melakukan tindak pidana terhadap kinerja saat menjadi bintara remaja hal ini dapat kita lihat dari pelanggaran yang dilakukan siswa Pendidikan bintara polri terhadap persentase sangsi yang diberikan kepada bintara remaja dan persentase penghargaan yang diterima oleh bintara remaja, artinya sangsi yang diberikan pada siswa melakukan pelanggaran saat pendidikan tidak berpengaruh terhadap kinerjanya saat bintara remaja tergambar dari lebih besarnya persentase sangsi yang diberikan kepada bintara remaja dari pada persentase penghargan yang diterima oleh bintara remaja, sedangkan berdasarkan kuesioner yang dibagikan kepada 80 responden dapat kita lihat pada jawaban dari pertanyaan no 6 yaitu pengaruh dari sanksi yang diberikan pada saat menjadi siswa memberikan efek jera terhadap siswa yang melakukan tindak pidana sehingga pada saat dinas menjadi bintara remaja tidak melakukan tindak pidana saat berdinas dan juga sangat berpengaruh terhadap rekan- rekan siswa lainnya yang melihat rekannya yang dikenakan hukuman karena melakukan pelanggaran ringan maupun tindak pidana terutama adanya pengaruh psikis terhadap rekan lainnya untuk tidak melakukan pelanggaran baik itu pelanggaran ringan hingga tindak pidana karen akan menimbulkan kerugian besar bagi pribadi orang yang melakukan hal tersebut.

\section{KESIMPULAN}

Pelaksanaan sanksi bagi siswa Diktukba Polri yang melakukan tindak pidana akan mengacu pada Pasal 41 Surat Keputusan Kapolri Nomor: SKEP / 194 / III / 2006 tertanggal 17 Maret 2012 dengan Pelanggaran ringan, Pelanggaran sedang, dan Pelanggaran berat. Terhadap pelanggaran pada butir 2 c butir 9, yaitu melanggar pidana, akan diadakan pemeriksaan sesuai proses hukum dan terhadap siswa yang melanggar pidana tersebut dapat dikenakan helm merah, pengurangan nilai mental kepribadian, pembentukan mental serta karakter dan dikeluarkan dari Pendidikan/dipecat. Kewenangan untuk memberikan hukuman berada kepada Kepala Lembaga Pendidikan. Pengaruh sanksi bagi siswa Diktukba Polri yang melakukan tindak pidana terhadap kinerja saat menjadi bintara remaja disimpulkan bahwa tidak ada pengaruh sanksi siswa diktukba polri yang melakukan tindak pidana terhadap kinerja saat bintara remaja, terlihat pada sikap dan tingkah laku sewaktu melakasanakan tugas.

Hal ini ditunjukkan dengan sanksi yang diberikan dan penghargaan yang diterima pada saat menjadi bintara remaja . Dari data 408 orang jumlah angkatan 2017 dan 2018 yang terkena sanksi 127 orang dan yang mendapat reward 18 orang, sedangkan berdasarkan kuisioner yang diberikan kepada responden menyebutkan ada pengaruh penting terhadap sanksi yang diberikan kepada siswa Diktukba Polri yang melakukan tindak pidana, dimana hal ini memberikan efek jera, membentuk mental kepribadian, psikologi dan karakter siswa 
yang melakukan tindak pidana tersebut dan juga rekan siswa lainnya sehingga pada saat menjadi bintara remaja tidak melakukan pelanggaran kode etik kepolisian.

\section{DAFATAR PUSTAKA}

\section{Buku-Buku:}

Burhan Asofa, Metode Penelitian Hukum, Rineka Cipta, Jakarta, 2010.

Dwi Haryadi, Kode Etik Profesi Hukum, UBPress, Malang, 2018.

Kepolisian Republik Indonesia, Buku Panduan tentang Hak Asasi Manusia untuk Anggota Polri, PTIK, Jakarta, 2006.

Kartini Kartono, Pengantar Metode dan Riset Sosial, Mandar Maju, Bandung, 1996.

Pudi Rahardi, Hukum Kepolisian, Profesionalisme dan Reformasi Polri, Laksbang Mediatama, Surabaya, 2007.

Dani Durahman, Penerapan Sanksi Terhadap Penyimpangan Penyidik Polri Dalam Menangani Perkara, Jurnal Ilmiah Universitas Batanghari Jambi Volume 16, Nomor 2 Tahun 2016.

\section{Peraturan Perundang-Undangan:}

Undang-undang Nomor 2 Tahun 2002 tentang Kepolisian Negara Republik Indonesia

Peraturan Kapolri Nomor 11 Tahun 2009 tentang pokok- pokok penyelenggaraan pendidikan dan pelatihan.

Peraturan Kapolri Nomor 14 Tahun 2011 tentang Kode Etik Profesi Kepolisian. 